\title{
Indices for Measuring Forest Ecosystem Goods and Services Contribution to the Rural Community: A Tool for Informed Decisions
}

\author{
Rajiv Pandey \\ HNB Garhwal University \\ Garhwal (Srinagar), Uttarakhand, India \\ Email:rajivfri@yahoo.com; rajiv.pandey@nic.in
}

\begin{abstract}
Forests provide immense goods and services to human beings. The utilization pattern of these goods and services varies at spatial and temporal scales to different communities reside near to the forest. Therefore, for management and conservation of forest of a region, the policies should be oriented on actual resource utilization by the dependent community. In this paper, the indices for evaluation of forestry's ecosystem goods and services contributions are being proposed based on measurable indicators of the forest resources utilized by local community. These indices analyze the spatio-temporal heterogeneity of resource use and explore the suitability of existing resource management option and may be used for policy instruments for developmental activities and for assessing with and without Reduced Emission due to Forest Degradation and Deforestation (REDD) scenarios. These indices are being evaluated and compared at spatial scale in the hills of Dehradun, India by collecting data on forest resource utilization through questionnaire survey from 200 randomly selected households distributed in 34 villages at two altitudes. The forest contribution among the communities was found to differ with altitude, indicating the need for an altitudinal basis for the forest management regime. Therefore, these indices may be used to obtain the information about the forest's contribution to the society at present and may facilitate future anticipated changes to adjust forest management to meet the need of society.
\end{abstract}

KEYWORDS: Forestry contribution, Ecosystem production function, Ecological and socio-economic assessment

\section{Introduction}

Forest represents one of the most complex and important ecosystems on the planet for various purposes and uses to the stakeholders (Byron and Arnold, 1999). Forests provide various ecosystem goods and services (EG\&S) to mankind and even food during adverse situation (Arnold, 1997). The forest EG\&S typically refers to the 
supply of valuable products and materials, the support and regulation of environmental conditions, and the provision of cultural and aesthetic benefits (Daily, 1997; DeFries et al., 2004). The dependence of these environmental resources for rural people in poor or developing countries is very important to the household economy (Cavendish, 2000; Mahapatra and Tewari, 2005).

The Millennium Ecosystem Assessment has identified various function and services of ecosystem and reported that communities rely on ecosystems for various goods such as food and timber, regulating services such as water purification, and cultural and aesthetic value. The various changes and drivers of change including climate change are affecting the capability of ecosystems services provided by tropical forests (Millennium Ecosystem Assessment, 2005). This affect in the capability of ecosystem, in turn influence the majority of rural households who derive their livelihoods from forests. This creates a double challenge of responding to these impacts on society and on their sources of livelihood. How these different roles and uses of forest are integrated into national planning and accounted for in global actions requires accurate reporting (Nkem, 2009).

The depletion of forest resources is largely because of policies that have promoted agricultural development, industrialization and colonization in most countries. This also raises a need for assessment of trade-off of the ecosystem goods and services being derived from forest ecosystems. The problem of forest degradation has been more serious as many forest goods and services are consumed by collectors, so no market prices are revealed, and hence they are often not taken into account in policy decisions. This may ultimately compromise the sustainability of natural resources and thus, humans of the biosphere in long term.

The assessment of forest goods and services to households is tedious mainly due to the complex relations of interactions among various ecosystem functions as well as the intermingled fabrics among the various sources of livelihood in rural households, which are variable, wide and seasonal. It becomes more important due to cross-scale phenomena in ecology and the inherent tradeoffs they represent due to its effects on human society and their interaction with different groups of people, each with different levels of vulnerability and control (Foley et al., 2007). The absence of monetary value or lack of formal markets for many of these natural goods and services makes the problem more severe. Therefore specialized valuation techniques are required to assess these (Cavendish, 2000).

The ecosystem valuation issue cannot be avoided, whenever decisions about the choices are required (Costanza and Folke, 1997). The ecosystem value to human wellbeing may be visualized through ecological value (which considers both the integrity of ecosystem functions and parameters), socio-cultural value (social values, equity and perceptions in addition to ecological criteria) and the economic value (estimated by market and non-market valuation). The choice of approach is based on the objective of assessment (de Groot et al., 2002). 
Numerous studies have been conducted to assess the value of ecosystem goods and services (EGS) at various scales across the world (Costanza et al., 1997; Daily et $a l ., 2000)$. Values placed by consumers on ecosystem goods and services can be observed directly while trading in the market. However, economic valuation is complex for ecosystem services due to the non-tradability. Traditional approaches for the valuation of ecosystem services emphasize either the economic system or the ecosystems, and do not consider the inter-relationships between these two systems. Furthermore these approaches are static and do not follow the unidentified trajectories of the valuation of ecosystem service associated with the evolution of structures and ecosystem processes in function of their main drivers of change (Winkler, 2006). Besides this, the lack of clear understanding of the various interactions of ecosystem services also leads to inappropriate valuation (Farley, 2008).

Therefore, the knowledge of ecological processes is a prerequisite for understanding the dynamics in ecosystems for ecosystem service valuation. This consideration overcome the limitations of economic and ecological valuation by incorporating values based on the individual preferences as well as considering a common value system (Andrade et al., 2010). The environmental values perceived by society are part of a broader structure valuation, since the society does not take into consideration only the economic values linked to certain flows of the ecosystem services, rather also considers various environmental interactions as per their traditional knowledge.

Hein et al., (2006) proposed a five steps framework for ecosystem services valuation. This includes: specification of the boundaries of the system to be valued; ecosystem services evaluation in biophysical terms; valuation by using monetary value or other indicators; Aggregation or comparison of different values; and analysis of scales and identification of stakeholders involved.

The Millennium Assessment (MA) framework is built on existing ecosystem service concepts and frameworks (Daily, 1997; de Groot et al., 2002). The MA simplified the presentation of ecosystem services concepts and placed them within a broader socio-economic-political context to help the informed policy development (Daily et al., 2009). These are being used to develop specific applications for different end users such as economic valuation (Fisher et al., 2009).

Numerous frameworks have been developed primarily with economic valuation in mind. The sequential nature of these frameworks can also support the use of metrics and indicators in applying ecosystem service concepts in policy analyses with the view to quantify multidimensional issues using indicators as proxies. The indicators are often combined into a composite index allowing diverse variables to be integrated. Definitions and classifications for ecosystem services have been proposed and debated (Fisher et al., 2008) and help to identify the respective indicators. Ahmad (2003) proposed an index termed as DIFRON (distance from nature) to measure the status of the fulfillment of basic physical needs of a family or 
society. The DIFRON Index is based on the logic that an ideal ecological society would be meeting all its basic physical and psychological needs from their locality through their labor without adversely affecting the environment and includes parameters, which provide the physical needs of society. Banzhaf (2005) proposed two theoretically consistent and empirically tractable ways that a cost-of-living index can be expanded to include the environment and other public goods with an empirical illustration. He suggested that inclusion of public goods can make a substantial difference in the index.

The Human Development Index incorporates life expectancy, health, education, and standard of living indicators for an overall picture of national wellbeing (UNDP?, 2007). The Water Poverty Index of Sullivan (2002) is integrated assessment of water stress and scarcity, linking physical estimates of water availability with socioeconomic variables that reflect poverty. Hahn et al., (2009) developed the Livelihood Vulnerability Index (LVI) to estimate climate change vulnerability. The LVI aggregates indicators of socio-demographics, livelihoods, social networks, health, food and water security, natural disasters and climate variability in terms of a composite index.

In covering sustainable development or sustainability in terms of a 'triple bottom line' with environmental, social and economic factors, as well as underlying endowments, accumulated harms, current policy efforts, and the prospect for changing future trajectories, the efforts of assessment have lost coherence and therefore policy relevance (Prescott-Allen, 2001). Thus, identifying an appropriate set of metrics is equally important, otherwise indicators are too broad to be of practical value (Esty et al., 2005). Environmental Sustainability Index was developed based on above logics (Esty et al., 2005) and the Environmental Performance Index (EPI) has been proposed. The EPI provides a path toward a world in which environmental targets are set explicitly, progress toward these goals is measured quantitatively, and policy evaluation is undertaken rigorously (Esty et al., 2008).

The proposed indices may overcome the limitation of traditional economic valuation methods by considering the individual preferences as well as the aggregate value of the system being valued. The intricacies lie with the identification and selection of suitable indicators. This also considers the Hein et al., (2006) framework.

The purpose of indices reported here was to estimate the contributions of forest ecosystem goods and services to the rural poor in an effective and unbiased way, and to compare their contribution on the spatio-temporal scale at micro and macro level by proposing indices to capture the forests contribution. This will facilitate the informed decision about the current situation and may advocate for future anticipated changes. These numerous EG\&S of forests may be filtered based on their importance to local people due to their most vulnerable nature in the absence of these services. These will serve the purposes because they are among the 
principal stakeholders, who ensure the maintenance of important processes and interactions within ecosystems, and they hold much of the information on the provision of EG\&S. The direct assessment of this interacting, interdependence and with multiple outputs can be addressed by defining the indicators that are measurable and serve as proxies for abstract and immeasurable. These indicators may assist indirectly for identifying problems on the horizon across, or adjudge the success of past policies in the present scenario besides evaluating public policies more directly as deduced by Banzhaf and Boyd, (2005).

\section{Proposed Measures of the Forest Goods and Services Contribution to the Community}

Measures or valuations of forest contribution fall under two broad categories, viz. direct utilization by community for one item and cumulative contributions of all the goods and services to the community. Direct contributions include goods and measurable services, such as, fuel wood, fodder, leaf and twigs, food material and employment as a wage labor in forest activities. These contributions can be measured separately for individual community on spatio-temporal basis and thus used for comparing among these for other policy formulation. The assessment may be possible by:

i. identification of households obtaining some products from forest on regular basis.

ii. using information on the identified households for construction of forest contribution measure.

\section{(a) Index for Single Contribution of Forest Ecosystem}

Three measures are proposed for the single contribution derived by the community.

Value Count Ratio: This is defined as the fraction of the number of households collecting a particular forest item $\left(N_{i}\right)$ to the total number of households $(\mathrm{N})$ in the village or community. Symbolically, the Value Count Ratio $\left(H_{j}\right)$ is $\mathrm{H}_{\mathrm{j}}=\mathrm{N}_{\mathrm{i}} / \mathrm{N}$, where $\mathrm{j}$ represents fuel or fodder, or employment or any other forest item being derived by the households. This index is insensitive to the distribution of quantities derived by the households or communities. In other words, fixing $N_{i}$ and changing the quantity collected by any extent will not influence $\mathrm{H}_{\mathrm{j}}$.

Value Quantity Measure: This is the fraction of total quantities of the item collected from forests by individual households to the total number of households in the village or the community. Suppose that there are $\mathrm{N}$ units (households) of which $N_{i}$ households are obtaining $Q_{1}, Q_{2}, \ldots, Q_{N_{i}}$ quantities of the item from forest. Then the Value Quantity Measure $\left(H_{Q_{j}}\right)$ is defined as 


$$
H_{Q j}=\sum_{i=1}^{N_{i}} Q_{i} / N
$$

where $\mathrm{j}$ represents goods (such as fuel fodder and other forest items being used by the households), services, and employment gained by households.

This measure incorporates the number of households collecting forest items and quantities collected by individual households. It overcomes the problem present in the Value Count Ratio. However, it does not reflect the variability of the quantities collected or other benefits gained by individual households by individual households. That is, if the total quantity is fixed and the number of households deriving contribution is varied, then this variation will not influence the measure.

Contribution Quantity Load Ratio: This is the ratio between the square root of variance of quantity of a forest item collected from forests to the mean quantity of the item collected or benefits gained in the village or the community. Suppose there are $\mathrm{N}$ units (say, households) of which $N_{i}$ households are obtaining items $Q_{1}, Q_{2}, \ldots, Q_{N_{i}}$ quantity from forests with the average $\bar{Q}$. Then the contribution quantity load ratio $\left(H C_{Q_{j}}\right)$ is defined as

$$
H C_{Q j}=\frac{\sqrt{\sum_{i}\left(Q_{i}-\bar{Q}\right)^{2} / N}}{\bar{Q}}
$$

where $\mathrm{j}$ represents fuel, or fodder, or employment or any other forest items being used by the households. This index accounts for absolute differences of the benefits gained or goods extracted.

These three indices may be used for assessing the contribution and accordingly inferences may be drawn under the consideration of their weaknesses.

\section{(b) Index for Forest Ecosystem Goods and Services Contribution to the Community}

The index is being proposed to measure the forest contribution based on indicators for all goods and services in totality perceived by the household. It will be known as the Forest Contribution Index, which gives an idea that how much a household, a locality or a society is deriving benefits from the forest ecosystem.

The index provides solutions for various abstract situations by combining various issues together with their marginal shares through assigning indicators. These indictors fulfill the considerations of social policy of human welfare and the index also accesses benefits for understanding the tradeoffs and setting of priorities as elaborated by Banzhaf and Boyd, (2005). The described method attempts to resolve 
the conflicting situations by capturing all the benefits derived from ecosystem, including intangible benefits arising from ethical, moral and spiritual beliefs.

\section{Description of Forest Contribution Index parameters}

The proposed FORCON Index considers four primary functions of the ecosystem defined by de Groot et al., (2000) through suitable indicators:

1. Regulation functions: These functions include the capacity of natural and semi-natural ecosystems to regulate essential ecological processes and life support systems through bio-geochemical cycles and other biospheric processes. In addition to maintaining ecosystem (and biosphere) health, these functions provide many services, which have direct and indirect benefits to humans (such as clean air, water and soil, and biological control services).

2. Habitat functions: These functions include the provision of natural ecosystems for habitat for the refuge, conservation and reproduction purposes to flora and fauna including evolutionary processes.

3. Production functions: These functions include the conversion capacity of energy, carbon dioxide, water and nutrients into a wide variety of carbohydrate for the use of secondary producers.

4. Information functions: These functions include the opportunity to obtain information related to evolution, reflection, spiritual enrichment, cognitive development, re-creation and aesthetic experience.

The first two function groups (regulation and habitat) are essential to the maintenance of natural processes and components, and are therefore conditional to the maintenance of the availability of the other two function-groups. Once the functions of an ecosystem are known, the nature and magnitude of value to human society can be analyzed and assessed through the goods and services provided by the functional aspects of the ecosystem. The ecosystem function-concept thus provides the empirical basis for the classification of (potentially) useful aspects of natural ecosystems to humans: observed ecosystem functions are reconceptualised as 'ecosystem goods or services' when human values are implied. The primary insight here is that the concept of ecosystem goods and services is inherently anthropocentric: it is the presence of human beings as valuing agents that enables the translation of basic ecological structures and processes into value-laden entities (de Groot et al., 2000).

All four functions of ecosystem are assigned equal weights with a maximum score of 25 points each out of 100 points, keeping in view of their importance and interlinkage with human survival. Equal weights are assigned to various parameters within each function depending upon the number of parameters. The binary system 
of weightage was assigned to those parameters, which cannot be measured directly or may not be quantified by the rural people. The yes and no response of binary system, though may not account the actual value, but may provide the abstract contribution.

These parameters are related directly or indirectly with the benefits derived by the households from forests for the functions. The index of the village or community is calculated by averaging the valuation for the households by either collecting data from individuals or from a group of through collective valuation. The Forest Contribution Index acronym as FORCON index would range from 0 to 100 points. The FORCON index may be represented as follows and the details of it have been reported in Table 1.

$$
\text { FORCON.Index }=\frac{\sum_{i} p_{i}}{100}
$$

Table 1: Description of FORCON parameters for goods and services of forest ecosystem

\begin{tabular}{|c|c|c|c|c|c|}
\hline $\begin{array}{c}\text { Ecosystem } \\
\text { Function } \\
\text { Group and } \\
\text { Type } \\
\end{array}$ & $\begin{array}{l}\text { Ecosystem } \\
\text { Functions }\end{array}$ & $\begin{array}{c}\text { Parameters for } \\
\text { Forest Derived } \\
\text { Services and } \\
\text { Goods } \\
\end{array}$ & Response & $\begin{array}{c}\text { Values } \\
(\mathbf{z})\end{array}$ & $\begin{array}{c}\text { Formulae } \\
\left(\mathbf{p}_{\mathbf{i}}\right)\end{array}$ \\
\hline \multicolumn{6}{|c|}{ Regulatory Function } \\
\hline $\begin{array}{l}\text { Gas } \\
\text { regulation }\end{array}$ & $\begin{array}{l}\text { Regulation of } \\
\text { atmospheric } \\
\text { chemical } \\
\text { composition. }\end{array}$ & $\begin{array}{l}\text { Influence } \\
\text { on Climate }\end{array}$ & $\begin{array}{l}\text { Yes } \\
\text { No }\end{array}$ & $\begin{array}{l}1 \\
0\end{array}$ & $\begin{array}{l}(25 . x \\
z) / 11\end{array}$ \\
\hline $\begin{array}{l}\text { Climate } \\
\text { regulation }\end{array}$ & $\begin{array}{l}\text { Regulation of } \\
\text { global } \\
\text { temperature, } \\
\text { precipitation, and } \\
\text { other biologically } \\
\text { mediated climatic } \\
\text { processes }\end{array}$ & $\begin{array}{l}\text { Maintenance of a } \\
\text { favored climate }\end{array}$ & $\begin{array}{l}\text { Yes } \\
\text { No }\end{array}$ & $\begin{array}{l}1 \\
0\end{array}$ & $\begin{array}{l}(25 . x \\
z) / 11\end{array}$ \\
\hline $\begin{array}{l}\text { Disturbance } \\
\text { regulation }\end{array}$ & $\begin{array}{l}\text { Capacitance, } \\
\text { damping and } \\
\text { integrity of } \\
\text { ecosystem } \\
\text { response to } \\
\text { environmental } \\
\text { fluctuations. }\end{array}$ & $\begin{array}{l}\text { Strom Protection } \\
\text { Flood Protection }\end{array}$ & $\begin{array}{l}\text { Yes } \\
\text { No }\end{array}$ & $\begin{array}{l}1 \\
0\end{array}$ & $\begin{array}{l}\text { (25.x } \\
z) / 22\end{array}$ \\
\hline
\end{tabular}




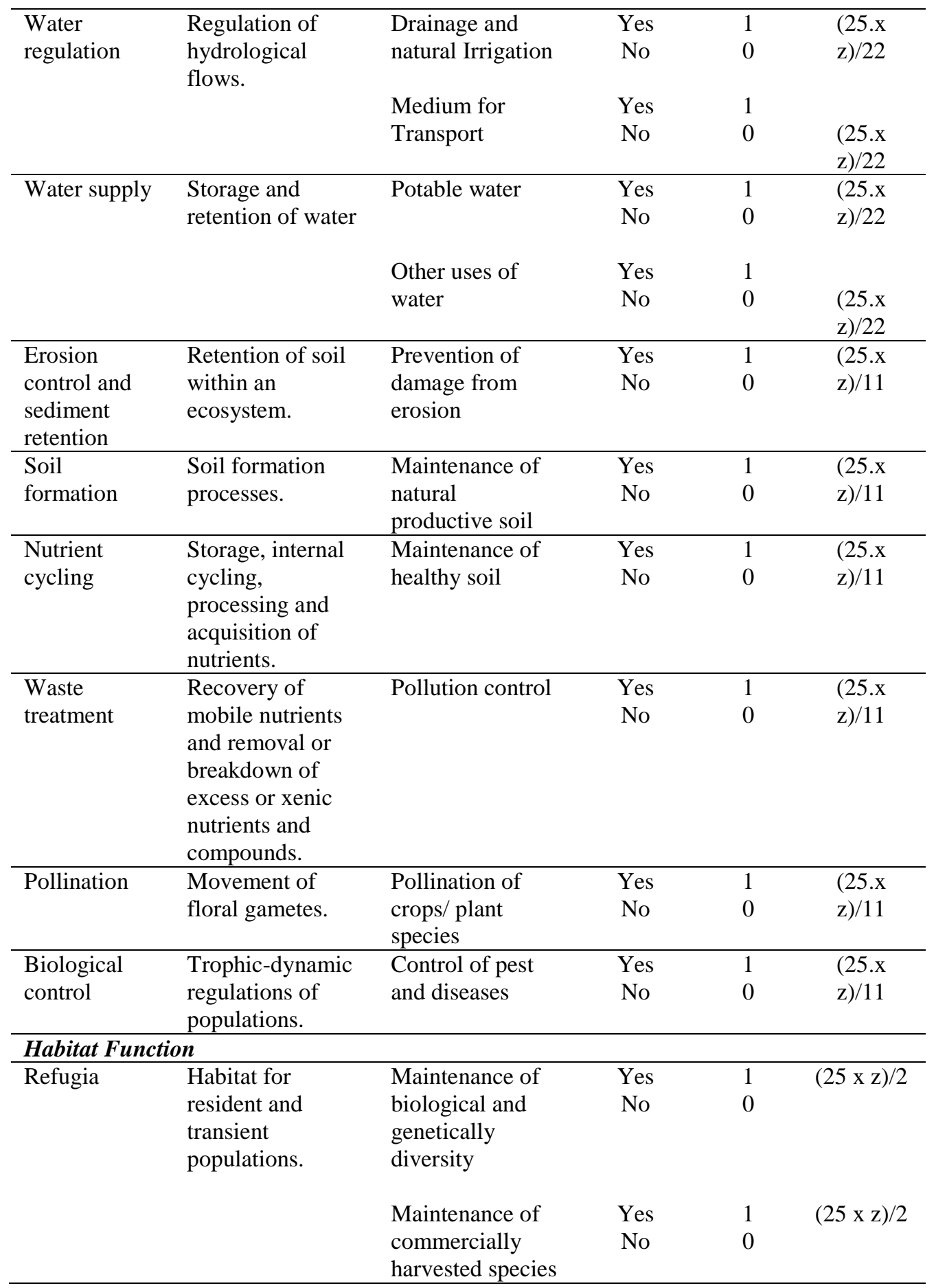




\begin{tabular}{|c|c|c|c|c|c|}
\hline \multicolumn{6}{|c|}{ Production Function } \\
\hline \multirow{6}{*}{$\begin{array}{l}\text { Food } \\
\text { production }\end{array}$} & \multirow{6}{*}{$\begin{array}{l}\text { Primary } \\
\text { production } \\
\text { extractable as } \\
\text { food. }\end{array}$} & Hunting & Yes & 1 & $(25 \times \mathrm{z}) / 9$ \\
\hline & & & No & 0 & \\
\hline & & Fruit Collection & Yes & 1 & $(25 \times z) / 9$ \\
\hline & & & No & 0 & \\
\hline & & Small scale & Yes & 1 & $(25 \times z) / 9$ \\
\hline & & $\begin{array}{l}\text { subsistence } \\
\text { farming }\end{array}$ & No & 0 & \\
\hline \multirow[t]{9}{*}{ Raw materials } & \multirow{9}{*}{$\begin{array}{l}\text { Primary } \\
\text { production } \\
\text { extractable as raw } \\
\text { materials. }\end{array}$} & Building & Yes & 1 & $(25 x$ \\
\hline & & $\begin{array}{l}\text { material i.e. } \\
\text { lumber }\end{array}$ & No & 0 & z)/12 \\
\hline & & Fuel wood & Yes & 1 & \\
\hline & & & No & 0 & $(25 x$ \\
\hline & & Organic manure & Yes & 1 & z)/12 \\
\hline & & and fertilizer & No & 0 & \\
\hline & & Fodder & Yes & 1 & $(25 x$ \\
\hline & & & No & 0 & z)/12 \\
\hline & & & & & $(25 \mathrm{x}$ \\
\hline \multirow{7}{*}{$\begin{array}{l}\text { Genetic } \\
\text { resources }\end{array}$} & \multirow{7}{*}{$\begin{array}{l}\text { Sources of unique } \\
\text { biological } \\
\text { materials and } \\
\text { products. }\end{array}$} & Improve crop & Yes & 1 & $(25 \times \mathrm{z}) / 9$ \\
\hline & & resistance to & No & 0 & \\
\hline & & $\begin{array}{l}\text { pathogens and } \\
\text { pests }\end{array}$ & & & \\
\hline & & Medicinal uses & Yes & 1 & $(25 \times z) / 9$ \\
\hline & & & No & 0 & \\
\hline & & Resources for & Yes & 1 & $(25 \times z) / 9$ \\
\hline & & $\begin{array}{l}\text { fashion, } \\
\text { handicrafts, } \\
\text { worships }\end{array}$ & No & 0 & \\
\hline \multicolumn{6}{|c|}{ Information Function } \\
\hline \multirow[t]{4}{*}{ Recreation } & \multirow{4}{*}{$\begin{array}{l}\text { Opportunities for } \\
\text { recreational } \\
\text { activities. }\end{array}$} & Enjoyment of & Yes & 1 & $(25 \times \mathrm{z}) / 4$ \\
\hline & & scenery & No & 0 & \\
\hline & & Travel for eco- & Yes & 1 & $(25 \times z) / 4$ \\
\hline & & $\begin{array}{l}\text { tourism or } \\
\text { outdoor sports }\end{array}$ & No & 0 & \\
\hline \multirow[t]{6}{*}{ Cultural } & \multirow{6}{*}{$\begin{array}{l}\text { Opportunities for } \\
\text { non-commercial } \\
\text { uses. }\end{array}$} & Use as motive in & Yes & 1 & $(25 \times z) / 6$ \\
\hline & & $\begin{array}{l}\text { books, paintings } \\
\text { etc }\end{array}$ & No & 0 & \\
\hline & & Use for religious & Yes & 1 & $(25 \times z) / 6$ \\
\hline & & purposes & No & 0 & \\
\hline & & Use for school & Yes & 1 & $(25 \times \mathrm{x}) / 6$ \\
\hline & & $\begin{array}{l}\text { excursions and } \\
\text { scientific } \\
\text { research }\end{array}$ & No & 0 & \\
\hline
\end{tabular}

(Costanza et al., 1997; de Groot et al., 2000). 
The percentage total of all the valuation of the above parameters would indicate how much forest is important for an individual or society in relative terms. The index has possibility of incorporating of additional sub functions within the functions with equal or unequal share of sub functions within the functions based on logical and conclusive findings.

\section{The Study Region}

The study region was Jaunsar, Dehradun, India lies between latitudes $30^{\circ}-31^{\prime} \mathrm{N}$ and $31^{\circ}-3^{\prime}-30^{\prime \prime} \mathrm{N}$ and longitudes $77^{\circ}-45^{\prime} \mathrm{E}$ and $78^{\circ}-7^{\prime}-20^{\prime \prime} \mathrm{E}$. The region is entirely composed of the succession of peculiarly rough and precipitous hills and mountains. The forest constituting 64\% of geographical area is potential resources for collections of fuel, fodder, grazing, timber and medicinal plants besides forest fruits, flowers and meat of wild animals. Jaunsar has a total of 14,399 households, consisting of smallholder communities of 18 to more than 60 families per village with a total population of 114,693 (Government of India, 2001). The communities' livelihood depends on agriculture (crop cultivation) and forest activities (collection of fuel wood, fodder, fruit and seeds) (Pandey, 2007). This region was selected for this study due to its remote location, large proportion of area under forest, and weak infrastructure including lack of proper education facilities to provide training for their livelihood options (Pandey and Bisht, 2006).

\section{Research Method for Empirical Evaluation of Proposed Indices}

For empirical evaluation of the proposed indices, the study region was classified into two altitude zones, viz. below $1000 \mathrm{~m}$ (Low zone, containing 204 villages) and from $1000 \mathrm{~m}$ to $1500 \mathrm{~m}$ (High Zone, containing 153 villages). From each zone, the households were selected at random through two-stage random sampling. In first stage, $10 \%$ villages were selected at random from each zone with the view that the number will suffice the intended objectives by capturing the inherent variability. The sampling unit, i.e. number of households was selected at random from the selected villages, proportionally to the size of villages (total number of households) in each zone. In total, 113 households were selected for first zone, and 87 households for second zone. The relevant data from the selected households of each zones, were collected through the pretested modified questionnaire, which enquires various household attributes (qualitative and quantitative in nature) and listing of various probable products of forests for household requirements. The questionnaire also contains the parameters for forest derived services and goods as per Table 1.

In both zones, families were found to be large in size (averaging about nine in the low hills and 10 in the upper hills). Primary profession of almost $70 \%$ households were farming in both zones. The size of the land holding was nearly 1.25 times more in high (3.75 ha) than low hills and the size of cattle units varied from 6 in high hills and 4 in low hills. The livestock rearing in hills are primarily to produce manure as most of them are unproductive in terms of milk (Pandey, 2007). In both the zones, households collect substantial quantities of forest resources including 
fodder, fuel wood, tubers and fruit for household use. They have high dependency on fuel wood for cooking energy because this is the primary source of cooking fuel.

The analysis of value count ratio showed that the contribution of forest for fodder is more in the high zone; however forests makes an important contribution for fuel wood in both zones (Table 2). The similar statistics for fuel wood was due to dependency of all households on forest fuel wood for cooking energy (similar findings of Pandey and Bisht, 2006). The higher value of index for fodder in the high zone may be attributed to the greater number of households rearing livestock. Also, household in remote high altitude locations with poor infrastructure, households may have greater interest in using manure as substitute to crop fertilizer. Similar result was observed for these parameters for value quantity measure (Table 2).

Table 2: Empirical evaluation of proposed indices

\begin{tabular}{|c|c|c|c|c|c|c|c|c|c|c|c|}
\hline \multirow[t]{2}{*}{ Zone } & \multicolumn{2}{|c|}{$\begin{array}{l}\text { Value } \\
\text { Count }\end{array}$} & \multicolumn{2}{|c|}{$\begin{array}{c}\text { Value } \\
\text { Quantity }\end{array}$} & \multicolumn{2}{|c|}{$\begin{array}{c}\text { Contribution } \\
\text { Quantity Load }\end{array}$} & \multicolumn{4}{|c|}{$\begin{array}{c}\text { Functions of FORCON } \\
\text { Index }\end{array}$} & \multirow{2}{*}{$\begin{array}{c}\text { Value of } \\
\text { FORCON } \\
\text { Index }\end{array}$} \\
\hline & $\mathbf{F u}$ & Fo & $\mathbf{F u}$ & Fo & $\mathbf{F u}$ & Fo & Reg & Hab & Pro & Inf & \\
\hline Hig & 1.00 & 0.9 & 24.47 & & 0.27 & 0.72 & 19.17 & 9. & 22 & 8. & 0 . \\
\hline Low & 1.00 & 0.94 & 22.60 & 30.40 & 0.34 & 0.64 & 16.43 & 5.52 & 16.93 & 5.88 & 0.45 \\
\hline
\end{tabular}

Fu : Fuel wood; Fo: Fodder; Reg: Regulatory; Hab: Habitat; Pro: Production; Inf: Information

This high value for fuel wood and livestock was based on total demand for these items by the households. The demand of forest products depend on the size of family, land holdings and livestock population (Pandey, 2007). Therefore the requirement was relatively high in the high hills, because they have more land and livestock. These all lead to high utilization of forest in the high hills. As well, for forest contribution quantity load ratio, the utilization of forest for fuel was most consistent in the high hills, more over for fodder; it was more consistent in low hills (Table 2). The greater variation for the contribution in the low hills was apparently not clear, moreover, the probable reason may be more extraction of fuel wood by some of households.

This also confirms that the contribution quantity load ratio is quantity sensitive with respect to the forest contribution (fuel, fodder etc.) and should be interpreted with greater cautions. In total, it can be concluded that a greater quantity of fodder is being extracted from forest areas. This clearly showed that these proposed indices may be used to evaluate the contribution of natural resources among various groups based on some measurable quantity with cautions with more preference to Contribution Quantity Load Ratio.

For the FORCON index, for all functions, forest utilization is greater for high zone based on the perceptions of the households of the region. As apparent the productive and regulation function has been rated high based on the associated services to these functions in both the zones. However, the other two functions, i.e. 
habitat and informative functions, contribute less than the regulation and production functions. The associated services for habitat and informative functions are generally, not affecting or contributing directly to the welfare of households, rather more pertinent to the habitat and informative services, therefore may not be well appreciated by the local poor communities (Table 2).

The high rating by the people of high zone was probably due to the more constrained life and high dependency on natural resources for various requirements of households as well as agriculture (mainly for rains, leaf litter and insect intensification) in the relatively remoteness settings and poor infrastructure in the region. As per respondent disclosure during survey, it can be deduced that these people of Jaunsar are dependent on forest to meet their requirements since generations in the specific settings of the nearby resources. Moreover, they are well versed with many of the potential benefits and use of the forests besides the problem associated with the loss of these forests including the calamities such as landslides and cloud burst. Even during survey, it was observed that they were aware about the association of water, climate particularly rainfall, nutrient cycling, erosion control role with the forest besides association of forest spread diseases to agriculture crops.

Though these sorts of knowledge were imprecise and based on observation only in the dearth of knowledge by the community about the critical scientific techniques; however the communities believe and respect these visualizations, which has been acquired by them since their generational transfer of traditional knowledge about these mechanism. On the other hand, the literacy level is very low in the region, with less than $50 \%$ of old persons being literate in both regions. The findings of FORCON clearly showed that the value of ecosystem goods and services differ at altitudinal basis, that is, the contribution realized and visualized by the community differs with altitude. Moreover, the visualization and realization was dependent on the individual capability to judge the system under the availability and access of resources and facilities to them besides their own observations and acquired knowledge. However, on average, it may consider that the response obtained showed the prevailing contribution of the forest and help to identify and characterize the important functions and parameters at local level.

The index varies between two altitudes, therefore, based on the result, it can be concluded that the differential requirements and demand of forest goods and services may be captured by the FORCON index. Thereby, suggest that the management regime for forest may acquire and gain the knowledge about the prevailing systems of resource utilization for anthropogenic purposes, and thus, necessary changes, if desired to be better suitable to the community may be incorporated or modified in the existing system for achieving the desired goals based on the FORCON index. 


\section{Synthesis of Indices}

The merits of use of index will provide a double benefit in a sense that not only facilitate the assessment but also improved insight into the ecosystem response and functions. The implementation part of the index requires careful measurement, ranking (assigning value to the entity), scale (range of use), and rightly assessing of overlapping sub indicators (the capability and ability), which are the potential sources of bias introduction in the assessing the value of these indices. The user responses and perceptions are being affected by a large number of intrinsic and extrinsic factors, thus may introduce error. These should be accounted through applying proper sampling strategy.

Scope exists for further refinement of the indices. The assigning of suitable weighting pattern (based on the marginal contribution of the entity) for various function or sub-functions in terms of the utility may be explored in addition to new or derived proxies for the existing functions or sub functions based on specificities of the system.

\section{Conclusions}

Ecosystem management approach may be classified in three ways. One approach focuses on the anthropocentric factors in ecosystem management with the aim to maximize the number of humans that can use a resource or ecosystem, subject to environmental constraints. A biocentric approach promotes sustainable human use while maintaining the ecological integrity of the ecosystem. The third, an ecocentric approach, promotes sustainable human use while managing at the eco-regional level with focuses on maintaining and restoring ecosystem function (Yaffe, 1999). However, the implementation of the management approach is being constrained due to minimal knowledge of ecosystem functions, and ignorance of immediate human demands on the landscape (Clark, 1999). The assessment of ecosystem based on index addresses both the constraints by directly describing the relevant ecosystem function and the current use by human, therefore, may support for better planning and decision support to the forest management.

Recognizing the ecosystem functions and their values will enable the society at large to make informed decisions about alterations in land use and land cover practices against any disturbances, as advocated by Pagiola et al. (2005). Forests have multifunctional uses to society, and quantifying the relative and full range of forests values may be helpful in designing forest management strategies (Wu et al., 2010). Forest management planning is facing increasing complexity due to the realization of various portfolios of forest goods and services, a societal demand for a rational, transparent decision process and threat due to climate change (Wolfslehner and Seidl, 2010). Therefore, it can be argued that forest management may be guided by the human beings' differential perception and utilization of forest resource base, based on the actual realization and uses. This evaluation leads to change in the management regime over time for deriving the intended goods and 
services without losing the intrinsic features of forests in terms of the quality and biodiversity.

These issues facilitate to formulate a framework that should be based on the cumulative sum total of the services derived from the nearby forests by the community, either quantitative wise such as volume or, qualitative wise such as perceptional attitude as per the anthropogenic appreciation. The perspective of the FORCON index lies in inclusiveness of all the assets of forests being in use of community, directly or indirectly, beneficial or detrimental as per perceptional analysis. This is with the view that the value judgment of the community for any services is based on the knowledge acquired from the belief and faith of their forefathers and experience gained with the close interaction of the system being valued, therefore, makes the assessment more vibrant and competent.

Besides this, the index is simple to derive (in terms of data collection) and to interpret for the rural poor, who are in general illiterate and have good traditional knowledge. Moreover the chance of modification also lies with the FORCON index. However, the limitation lies with the lack of extant of exact quantification of forest derived services, contrary to the fact that the precise quantification of various services being utilized by the community is massive and immeasurable (Cavendish, 2000; Boyd, 2004; Banzhaf and Boyd, 2005). These issues and facts provide the strength of application of the index for evaluation of forest management regime in changing perspective, and may guide for future discourse.

The novelty of the index-based assessment of ecosystem goods and services to the social value and equity lies in total anthropogenic perspective of an ecosystem, by increasing capabilities and freedoms of evaluating individual responses of each components of the system. The proposed indices may facilitate for better informed decisions for managing different ecosystems or land uses at various spatio-temporal level, if estimated properly within the permissibility specificities and acceptability of people. The resultant analysis will adjudge the success and failure of present policy and directed towards the adjustments.

The index also facilitate to distinguish between ecosystems which may be intended to provide only services (such as climate regulation) and those which constitute a unique biodiversity rich habitat and support to human and other life, in addition. The more insight of overall assessment of these ecological services may also provide information for prioritization of ecosystem goods and services for sustainable land use practices, promotion of off-farm incomes to the dependent communities, restoration of degraded sites, biodiversity conservation, water resources and hydro-power development, promoting community based management. 


\section{References}

Ahmad, S. (2003). "The DIFRON (Distance From Nature) Index" XII World Forestry Congress, 21-28 Sept., 2003, Quebec City, Canada.

Andrade, D. C., A. R. Romeiro, R. Boumans, R.P. Sobrinho and S.G. Tôsto (2010). "New methodological perspectives on the valuation of ecosystem services: toward a dynamic-integrated valuation approach. International Society for Ecological Economics Conference: Advancing Sustainability in Time of Crisis" Oldenburg and Bremen Germany, 22-25 August 2010.

Arnold, J. E. M. (1997). "Social dimensions of forestry's contribution to sustainable development” XI World Forestry Congress, 13-22 Oct., Antalya, Turkey.

Banzhaf, H. S. and J. Boyd (2005). "The Architecture and Measurement of an Ecosystem Services Index" RFF Discussion Paper 05-22, Resources for the Future, Washington.

Banzhaf, H. S. (2005). "Green price indices" Journal of Environmental Economics and Management, 49(2): 262-280.

Boyd, J. (2004). "What's Nature Worth? Using Indicators to Open the Black Box of Environmental Valuation" Resources (summer): 18-22.

Byron, N. and J. E. M. Arnold (1999). "What futures for the people of the tropical forests?" World Development, 27(5): 789-805.

Cavendish, W. (2000). "Empirical regularities in the poverty-environment relationship of rural households: Evidence from Zimbabwe" World Development, 28(11): 19792003.

Clark, R.J. (1999). "The ecosystem approach from a practical point of view" Conservation Biology, 13(3): 679-681.

Costanza, R. and C. Folke (1997). "Valuing ecosystem services with efficiency, fairness and sustainability as goals" Island Press, Washington.

Costanza, R., R. d'Arge, R.S. de Groot, S. Farber, M. Grasso, B. Hannon, K. Limburg, S. Naeem, R.V. O'Neill, J. Paruelo, R.G. Raskin, P. Sutton and M. van den Belt (1997). "The Value of the World's Ecosystem Services and Natural Capital" Nature, 387:253-60.

Daily, G. C. (1997). "Introduction: what are ecosystem services?” In G. C. Daily (Ed.), Natures services: societal dependence on natural ecosystems, Island Press, Washington.

Daily, G. C., S. Polasky, J. Joshua Goldstein, P. M. Kareiva, H. A. Mooney, L. Pejchar, T. H. Ricketts, J. Salzman, and R. Shallenberger (2009). "Ecosystem services in decision-making: Time to deliver" Frontiers in Ecology, 7(1): 21-28.

Daily, G. C., T. Söderqvist, S. Aniyar, K. Arrow, P. Dasgupta, P. R. Ehrlich, C. Folke, A. Jansson, B. Jansson, N. Kautsky, S. Levin, J. Lubchenco, K. Maler, D. Simpson, D. 
Starrett, D. Tilman And B. Walker (2000). "The Value of Nature and the Nature of Value" Science, 289(5478): 395-396.

De Groot, R. S., P. J. van der, A. Chiesura and S. Marguliew (2000). ”Ecological Functions and Socio-economic Values of Critical Natural Capital as a measure for Ecological Integrity and Environmental Health" In: P. Crabbe, A. Holland, L. Ryszkowski and L. Westra (eds.) 'Implementing Ecological Integrity: restoring regional and global environmental and Human Health'. NATO-Science Series, IV. Earth and Environmental Sciences Vol. 1, Kluwer Academic Publications, London. pp. 191214.

de Groot, R. S., A. W. Wilson and R. M. J. Boumans (2002). "A typology for the classification, description and valuation of ecosystem functions, goods and services" Ecological Economics, 41(3): 393-408.

DeFries, R. S., J. A. Foley and G. P. Asner (2004). "Land-use choices: balancing human needs and ecosystem function" Front Ecol Environ, 2 (1): 249-57.

Esty, D. C., M. A. Levy, C. H. Kim, A. de Sherbinin, T. Srebotnjak and V. Mara (2008). "2008 Environmental Performance Index" New Haven: Yale Centre for Environmental Law and Policy, Yale University, Connecticut.

Esty, D.C., M. A. Levy, T. Srebotnjak and A. de Sherbinin (2005). "The 2005 Environmental Sustainability Index: Benchmarking National Environmental Stewardship" New Haven: Yale Center for Environmental Law and Policy, Yale University, Connecticut.

Farley, J. (2008). "The role of price in conserving critical natural capital" Conservation Biology, 22(6): 1399-1408.

Fisher, B. and K. Turner (2008). "Ecosystem services: Classification for valuation" Biological Conservation, 141(5): 1167-1169.

Fisher, B., R. Costanza, R. K. Turner and P. Morling (2009). "Defining and Classifying Ecosystem Services for Decision Making" CSERGE Working Paper, EDM 07-04, UEA, Norwich.

Foley, J.A., G. P. Asner, M. H. Costa, M.T. Coe, R. DeFries, H. K. Gibbs, E. A. Howard, S. Olson, J. Patz, N. Ramankutty and P. Snyder (2007). "Amazonia revealed: forest degradation and loss of ecosystem goods and services in the Amazon Basin" Front Ecol Environ, 5(1): 25-32.

Hahn, M. B, A. M. Riederer and S. O. Foster (2009). "The Livelihood Vulnerability Index: A pragmatic approach to assessing risks from climate variability and change - A case study in Mozambique" Global Environ. Change, 19(1): 74-88.

Hein, L., K. Van Koppen, R. S. de Groot, and E. C. Van Ierland (2006). "Spatial scales, stakeholders and the valuation of ecosystem services" Ecological Economics, 57(2), 209-228. 
Mahapatraa, A. and B. D. Tewari (2005). "Importance of non-timber forest products in the economic valuation of dry deciduous forests of India" Forest Policy and Economics, 7(3): 455- 467.

Millennium Ecosystem Assessment. (2005) "Ecosystem and human well being: synthesis" Island Press and World Resources Institute, Washington, DC.

Nkem, J., D. Oswald, D. Kudejira and M. Kanninen (2009). "Counting on forests and accounting for forest contributions in national climate change actions" Working Paper 47, Centre for International Forestry Research, Bogor.

Pagiola, S., Konard von Ritter and J. Bisoph (2005). "How Much is an Ecosystem Worth? Assessing the Economic Value of Conservation" IUCN, The Nature Conservancy and The World Bank, Washington.

Pandey, R. (2007). "Contribution of forestry - Role in socio-economic of Jaunsaries and development of index" Unpublished Ph.D. thesis in FRI University, Dehradun.

Pandey, R. and N. S. Bisht (2006). "Household Characteristics And Forest Resource Utilization Linkages in Hills of Uttaranchal: A Case Study" The Ninth Biennial Conference on 'Ecological Sustainability and Human Well-Being', $15-18$ December 2006, New Delhi.

Prescott-Allen, R. (2001). "The Wellbeing of Nations. A Country-by-Country Index of Quality of Life and the Environment" Island Press, Washington.

Registrar General of India. (2001). "Housing profile: Uttaranchal” Registrar General, India, New Delhi.

Sullivan, C. (2002). "Calculating a water poverty index" World Development, 30(7): 11951210.

UNDP. (2007). “Human Development Report 2007/2008” UNDP, New York.

Winkler, R. (2006). "Valuation of ecosystem goods and services. Part 1: An Integrated dynamic approach" Ecological Economics, 59(1), 82-93.

Wolfslehner, B. and R. Seidl (2010). "Harnessing ecosystem models and multi-criteria decision analysis for the support of forest management" Environ Manage., 46(6):850-61.

Wu, S., Y. Hou and G. Yuan (2010). "Valuation of forest ecosystem goods and Services and forest natural capital Of the Beijing municipality, China" Unasylva, 61(234\&235): 28-36.

Yaffee, S. (1999). "Three faces of ecosystem management" Conservation Biology, 13(3):713-725. 